\title{
Carbon Footprint Analysis of Napier Pakchong 1 Grass Plantation in Prachinburi Province
}

\author{
Thanutyot Somjai ${ }^{1,}$, and Chalita Suwan ${ }^{2}$ \\ 1D epartment of Industrial M anagement, Faculty of Industrial Technology and M anagement, King M ongkut's U niversity of Technology \\ N orth B angkok (Prachinburi Campus), Prachinburi, Thailand \\ ${ }^{2}$ Department of Construction D esign and M anagement, Faculty of Industrial Technology and M anagement, King M ongkut's U niversity \\ of Technology N orth Bangkok (Prachinburi Campus), Prachinburi, Thailand
}

\begin{abstract}
This study aimed to analyze the holistic amount of greenhouse gas emission of $\mathrm{N}$ apier Pakchong 1 grass plantation in Prachinburi Province, Thailand, in a term of carbon footprint. The carbon footprint of Napier plantation from irrigation plot and non-irrigation plot was 17.182 and $19.138 \mathrm{~kg} \mathrm{CO}{ }_{2}$ e/ton of N apier Pakchong 1 grass, respectively. The largest contribution to the greenhouse gas emission came from the fertilizer application. The irrigation to the crop significantly increased the crop yield resulting in the reduction of greenhouse gas emission per unit weight of the crop. The suitable type and the optimal quantity of fertilizer application, as well as the most efficient irrigation system with the least environmental impact, were suggested for further study.
\end{abstract}

\section{Introduction}

Thailand increasingly relies on energy imports to sustain its rising energy demand. In 2018, energy consumption in Thailand was 83,691 ktoe, grew by 3.6 percent compared to 2017 . The imported energy amounted to $83,055 \mathrm{ktoe}$, grew by $5.2 \%$ compared to 2017 . Besides, energy consumption is mainly from fossil-based sources [1]. Therefore, Thailand is in an unsafe position in terms of energy security and greenhouse gas emissions. A lternative energy must be a foremost policy for energy security and environmental -friendly society in Thailand.

The Thai government announced its Alternative Energy Development Plan 2018 (A EDP 2018), which was issued in 2018 towards 2037, aiming to strengthen the country's energy security and raise the ratio of power generated from renewable sources. Renewable energy will contribute $29,358 \mathrm{MW}$ to total power production, accounting for 33 percent of Thailand's power generation in 2037. A mong renewable power resources in 2037, according to the latest amendment of the AEDP 2018, solar power is expected to contribute $15,574 \mathrm{MW}$, while the contribution of biomass power is $5,786 \mathrm{MW}$, wind power 2,989 M W, hydropower 3,000 M W, and wastesourced power $900 \mathrm{M} \mathrm{W}$ [2].

Energy crop plantations such as fast-growing plants and grasses have received attention in recent years to increase the potential of renewable power generation. $N$ apier grass (Pennisetum purpureum), a native plant of A frica, has the advantages of fast growth, disease and drought resistance, growth in a wide range of soil types, and harvestable biomass up to 4 times a year. It, thus, has been considered as an energy crop because it has a high yield of biomass $[3,4]$. Recently, the ministry of energy has a plan to push to bring Napier grass back to produce electricity after discontinuing since 2014 [5].

To produce electricity from Napier grass, there must be sufficient raw material which closes to the power plant to be convenient and save transportation cost. Energy Policy and Planning Office, M inistry of Energy reported in the study of energy conservation and renewable energy potentials that the potential of renewable energy in Prachinburi Province has not been sufficient to replace the use of fossil fuel [6]. If the relevant parties have seen the noteworthiness and support the plantation of energy crops like $\mathrm{N}$ apier grass, it will be able to build confidence for the energy producers to invest in alternative energy production.

Besides, the promotion of bringing $N$ apier grass to produce electricity should be considered along with environmental awareness especially greenhouse gas emission. There have been relatively few studies on the environmental impact assessment of $\mathrm{N}$ apier. One study analyzed the environmental impact of Napier grass as a feedstock for anaerobic digestion to produce el ectricity at the Royal Chitralada Projects (Bangkok) in Thailand, which focused on the comparative fertilizer applications [7]. The study indicated that the stage of Napier grass plantation was a hotspot of environmental impact through life cycle assessment and suggested the analysis of optimal fertilizer quantity of $\mathrm{N}$ apier crop as the best way to reduce environmental impact. A nother study analyzed the carbon footprint of Napier plantation in Phitsanulok, Thailand, which indicated that fertilization remarkably contributed to the highest greenhouse gas emission [8].

Beside fertilizer application, another key factor for Napier grass production is water supply to allow high yield production. Since the yield of $\mathrm{N}$ apier varies by water supply and plantation area [9], investigation of greenhouse 
gas emission should, therefore, be conducted in the targeted area.

Napier grass ( $P$. purpureum) originated from A frica where it is called Giant King Grass. It is one of the important renewable energy sources because it has a high yield of biomass and bio-methane [7]. The appearance of Napier grass likes sugarcane with thick and wide leaves. Napier Pakchong 1 grass is a hybrid Napier grass, by crossing $P$. purpureum and $P$. glaucum, with specific characteristics which are fast growth with forage yield, high carbohydrate and protein concentration, and wide range of adaptation [10]. The chemical composition of fresh N apier grass consists of $43.2 \% \mathrm{C}, 5.61 \% \mathrm{H}, 41.19 \%$ $\mathrm{O}$, and $1.22 \% \mathrm{~N}$ [11], which can produce up to $46.17 \%$ of methane gas [12]. Using Napier grass for energy production can be directly used as biomass for power plants or anaerobically digested to produce compressed biogas (CBG) for electricity production or as an al ternative for exhausting compressed natural gas (CNG) and as a substitute liquid petroleum gas (LPG).

This study aimed to analyze the holistic amount of greenhouse gas emissions of Napier Pakchong 1 grass plantation in Prachinburi Province on a comparative of irrigation and non-irrigation plots using "Carbon Footprint" as a tool. The functional unit, providing a reference to which the inputs and outputs are related, was defined as " 1 ton of Napier Pakchong 1 grass" Also, the study identified hotspot and provided information on the possibility of reducing greenhouse gas emissions from Napier Pakchong 1 grass plantation.

\section{Methodology}

\subsection{Study site}

The study was carried out at K ing M ongkut's U niversity of Technology North Bangkok, Prachinburi Campus, in Prachinburi Province in 2014. Two plots were prepared with covered an area of 1 rai (1,600 sq.m) each. One plot was an irrigated area that received sufficient water and another plot was a non-irrigated area that received seasonal water. In 2014, the temperature was recorded at Prachinburi meteorological station at $16-41^{\circ} \mathrm{C}$. The total rainfall was $1,494 \mathrm{~mm}$ a year [13]. Information from the guideline reported that the optimal temperature and annual rainfall for $\mathrm{N}$ apier Pakchong 1 grass plantation are more than $20^{\circ} \mathrm{C}$ and $1,000 \mathrm{~mm}$, respectively [14]. Therefore, Prachinburi is a spatial possibility of planting Napier Pakchong 1 grass.

\subsection{Life cycle assessment and carbon footprint}

In this study, a life cycle assessment (LCA) was used as an evaluation tool. LCA compiles and evaluates the inputs, the outputs and the potential environmental impacts of a product system throughout its life cycle [15]. LCA considers the entire life cycle of products or services from cradle-to-grave (from raw material acquisition through production, use, and disposal). It is thus a holistic assessment methodology of products or services. LCA has been proven to be a valuable tool to document the environmental considerations that need to be part of decision-making towards environmental sustainability [16].

The carbon footprint (CF) is based on LCA but focuses on a single issue which is global warming. It is expressed in terms of the amount of carbon dioxide $\left(\mathrm{CO}_{2}\right)$, plus its equivalent $\left(\mathrm{CO}_{2} \mathrm{e}\right)$ of other greenhouse gas emissions specified by the Kyoto Protocol including methane $\left(\mathrm{CH}_{4}\right)$, nitrous oxide $\left(\mathrm{N}_{2} \mathrm{O}\right)$, hydrofluorocarbons (HFCs), perfluorocarbons (PFCs) and sulfur hexafluoride $\left(\mathrm{SF}_{6}\right)$. The results from carbon footprint assessing offer valuable background information for strategic and operative planning as well as constructing a climate policy to mitigate climate change effects.

\subsection{System boundary}

The system boundaries of this study were illustrated in Fig. 1. The system boundaries included soil preparation, planting, fertilization, irrigation and harvesting, as well as the productions of resources and energy used during plantation. Transportation of Napier Pakchong 1 grass logs was excluded from the system boundary.

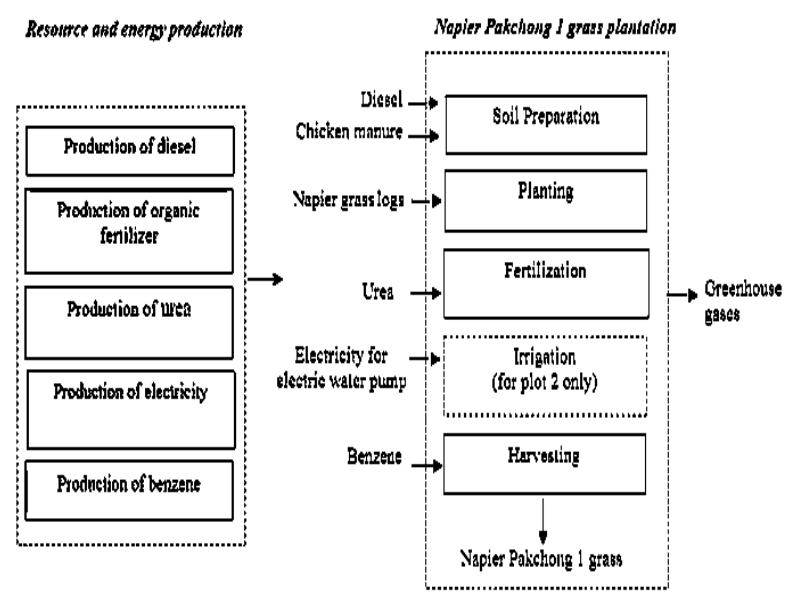

Fig. 1. The system boundaries of the study.

\subsection{Carbon footprint analysis of Napier Pakchong 1 grass plantation}

A mounts of resource and energy consumption related to the system boundaries were directly collected from the study plots. The estimation of greenhouse gas emissions from all plantation activities carried out in accordance with the guidelines for product carbon footprint assessment developed by the technical committee of the carbon footprint for product and service, TGO (Thailand) [17]. The amount of greenhouse gas emissions was estimated from the multiplication amount of resource or energy and emission factor obtained from the national database and other literature (Table 1 ) as shown in Eq. 1 and expressed as the amount of $\mathrm{CO}_{2}$ equivalent $\left(\mathrm{CO}_{2} \mathrm{e}\right)$.

$$
\mathrm{CO}_{2} e=\text { activity data } x \text { emission factor }
$$


Table 1. Greenhouse gas emission factors

\begin{tabular}{|c|c|c|c|}
\hline Activity & Unit & $\begin{array}{c}\text { Emission factor } \\
\text { (kg COO} 2 \mathrm{e} / \text { unit) }\end{array}$ & Sources \\
\hline $\begin{array}{l}\text { 1. Resource and energy } \\
\text { production } \\
\text { 1.1 Diesel } \\
\text { 1.2 Chicken manure } \\
\text { 1.3 U rea } \\
\text { 1.4 Electricity } \\
\text { 1.5 B enzene }\end{array}$ & $\begin{array}{c}\mathrm{kg} \\
\mathrm{kg} \\
\mathrm{kg} \\
\mathrm{kWh} \\
\mathrm{L}\end{array}$ & $\begin{array}{l}0.3504 \\
0.1097 \\
3.3036 \\
0.6933 \\
0.4005\end{array}$ & [18] \\
\hline $\begin{array}{l}\text { 2. Plantation } \\
\text { 2.1 Combustion of diesel } \\
\text { for soil preparation } \\
\text { 2.2 Chicken manure } \\
\text { application for soil } \\
\text { preparation } \\
\text { 2.3 U rea application for } \\
\text { plant nourishing }\end{array}$ & $\mathrm{kg}$ & $\begin{array}{r}2.745 \\
0.3157\end{array}$ & [19] \\
\hline $\begin{array}{l}\text { 2.4 Combustion of } \\
\text { benzene for } \\
\text { harvesting }\end{array}$ & L & 2.18156 & \\
\hline
\end{tabular}

\section{Results and discussion}

\subsection{Napier Pakchong 1 grass plantation in Prachinburi}

This study reported the activities relating Napier Pakchong 1 grass plantation in Prachinburi as follows:

\subsubsection{Soil Preparation}

In the preparation of the soil, tractors were used for tillage. A mount of diesel consumption for primary tillage, secondary tillage and trenching were $5.5 \mathrm{~L}, 4.5 \mathrm{~L}$, and $4.5 \mathrm{~L}$ per 1 rai (1,600 sq.m.), respectively. The Chicken manure was applied $300 \mathrm{~kg} / \mathrm{rai}$ for soil preparation.

\subsubsection{Planting}

Napier Pakchong 1 grass logs around 1.5 tons/rai were planted in the plots using human labor. The first crop started in J uly 2014 which was the rainy season.

\subsubsection{Fertilization}

U rea (N PK 46-0-0) was applied to the plots with the amount of $10 \mathrm{~kg} / \mathrm{rai}$ after the first harvesting around 1 month.

\subsubsection{Irrigation}

Two comparative options of Napier Pakchong 1 grass plantation: irrigation and non-irrigation were investigated. Off the rainy season, only in the irrigation plot, the grass was watered once a week. Electricity supplied for the electric water pump was $90 \mathrm{kWh} / \mathrm{rai}$, approximately.

\subsubsection{Harvesting}

The first period for harvesting Napier Pakchong 1 grass was 75 days after plantation, which was in October 2014. A fter that, it was harvested in every 45 days because its characteristics of biomass gave the highest yield of biogas production. The second and third harvesting were in January and A pril 2015. The yield of Napier Pakchong 1 grass was reported in Table 2 . K napsack mowers were used for harvesting. Gasoline consumption by the mowers was $1.41 \mathrm{~L} /$ rai.

Table 2. The yield of $\mathrm{N}$ apier Pakchong 1 grass

\begin{tabular}{ccc}
\hline \multirow{2}{*}{$\begin{array}{c}\text { Harvesting } \\
\text { time }\end{array}$} & \multicolumn{2}{c}{$\begin{array}{c}\text { Weight of fresh Napier Pakchong } 1 \text { grass } \\
\text { (ton/rai) }\end{array}$} \\
\cline { 2 - 3 } & Irrigation plot & Non-irrigation plot \\
\hline October 2014 & 9.80 & 8.02 \\
January 2015 & 6.00 & 4.30 \\
A pril 2015 & 2.10 & 0.49 \\
Total & $\mathbf{1 7 . 9 0}$ & $\mathbf{1 2 . 8 1}$ \\
\hline
\end{tabular}

\subsection{Carbon footprint analysis of Napier Pakchong 1 grass plantation in Prachinburi.}

Greenhouse gas emissions from Napier Pakchong 1 grass plantation were calculated and illustrated in Table 3 and Fig. 2. The carbon footprint of Napier Pakchong 1 grass plantation from irrigation plot and non-irrigation plot was 17.182 and $19.138 \mathrm{~kg} \mathrm{CO}_{2} \mathrm{e} /$ ton of Napier Pakchong 1 grass, respectively.

Fertilization remarkably contributed to greenhouse gas emissions either from the fertilization production or from the application. The fraction of greenhouse gas emission from fertilization was $64.18 \%$ and $80.52 \%$ for irrigation plot and non-irrigation plot, respectively. The application of chicken manure up to $300 \mathrm{~kg} /$ rai predominantly contributed to greenhouse gas.

The only difference in inventory data of the investigation of Napier plantation in an irrigation plot compared to which in a non-irrigation plot was electricity consumption. The amount of electricity consumption to supply for electric water pump of $90 \mathrm{kWh}$ was accounted for the irrigation plot plantation. The result of watering for the grass in the irrigation plot affected the increasing yield of the crop. Although the greenhouse gas emission from electricity production was accounted for, the carbon footprint of Napier Pakchong 1 grass plantation of irrigation plot, illustrated per unit weight of the crop, was less than which of the non-irrigation plot.

To produce $1 \mathrm{MW}$ of electricity from biogas, fresh Napier grass is needed for anaerobic digestion 166 tons/day [20]. Therefore, using Napier grass from the irrigation plots contributes less greenhouse gas emission around $324.7 \mathrm{~kg} \mathrm{CO}{ }_{2} \mathrm{e} /$ day compared to the using which from the non-irrigation plots. As the greenhouse emission factor of the Thai national el ectricity production of 0.6933 $\mathrm{kgCO}_{2} \mathrm{e} / \mathrm{kWh}$, the amount of greenhouse gas $324.7 \mathrm{~kg}$ $\mathrm{CO}_{2} \mathrm{e}$ that can be reduced equivalents to the amount of greenhouse gas of the Thai national electricity production $468 \mathrm{kWh}$.

This study suggested further study of the suitable type and the optimal quantity of fertilizer applied for Napier Pakchong 1 grass plantation. The most efficient irrigation system with the least environmental impact should either be considered. 
Table 3. Greenhouse gas emission from Napier Pakchong 1 grass plantation in Prachinburi Province.

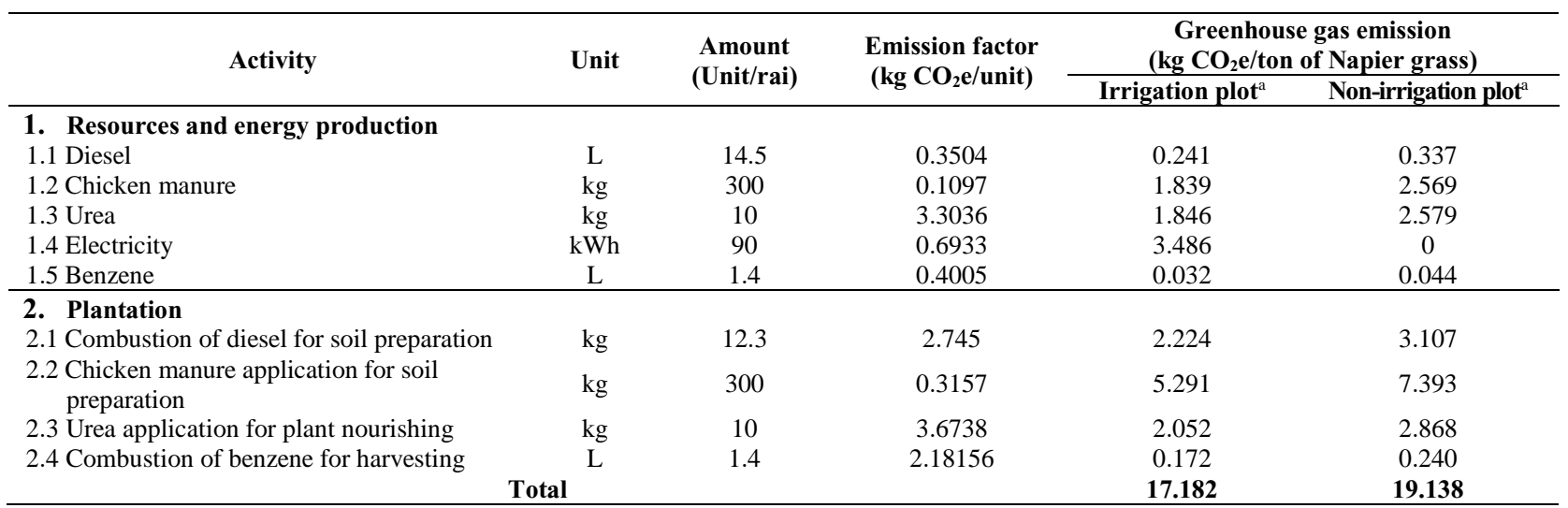

aThe yields of Napier Pakchong 1 grass from irrigation plot and non-irrigation plot were 17.90 and 12.81 ton/rai, respectively.

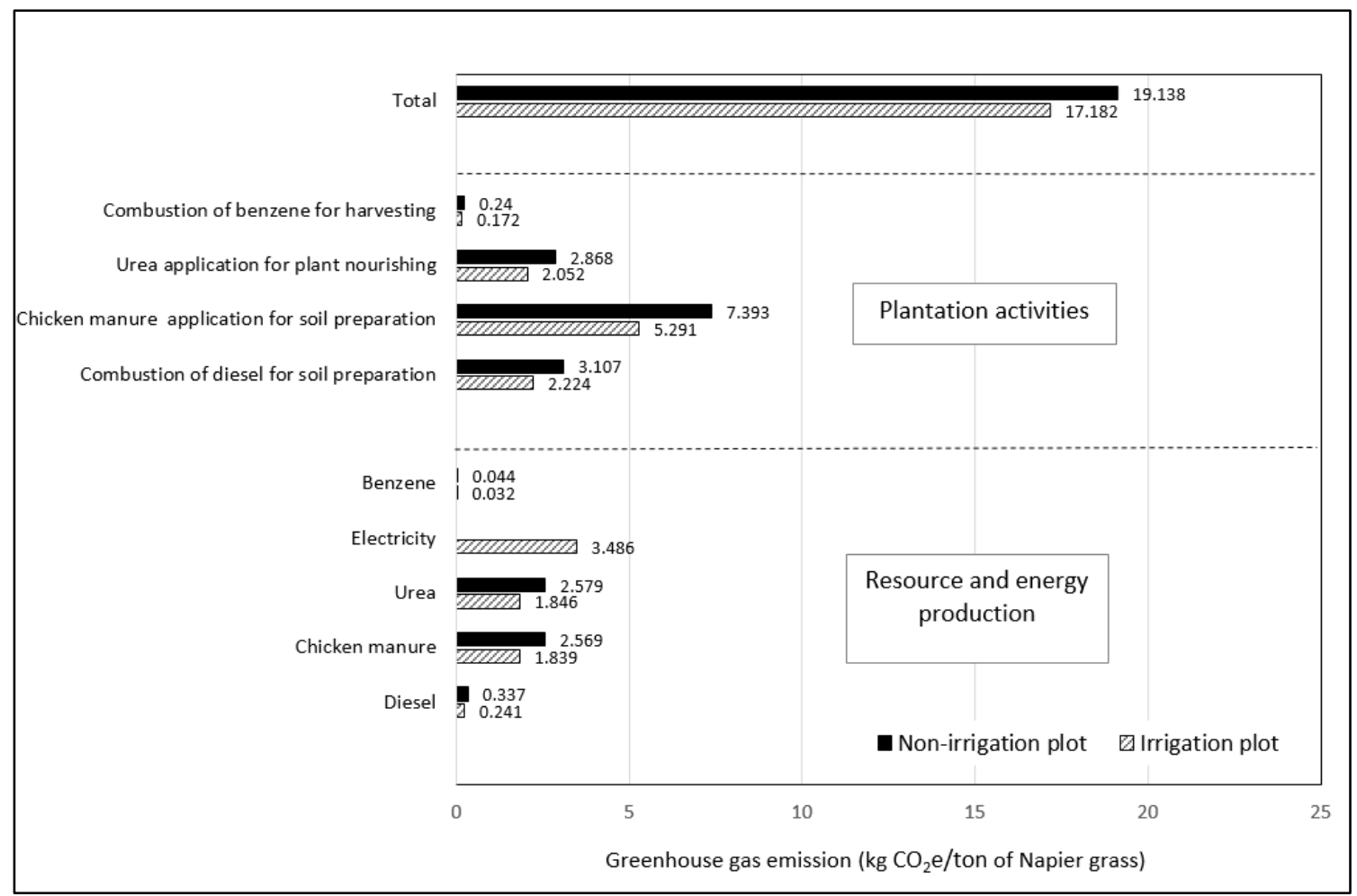

Fig. 2. Greenhouse gas emission from Napier Pakchong 1 grass plantation in Prachinburi Province.

\section{Conclusion}

This study estimated the carbon footprint of N apier Pakchong 1 grass plantation in Prachinburi Province, Thailand. The carbon footprint of Napier plantation from irrigation plot and non- irrigation plot was 17.182 and $19.138 \mathrm{~kg}$ $\mathrm{CO}_{2} \mathrm{e}$ /ton of Napier Pakchong 1 grass, respectively. The largest contribution to the greenhouse gas emission came from fertilizer application. The irrigation to the crop significantly increased the crop yield resulting in the reduction of greenhouse gas emissions per unit weight of the crop. The suitable type and the optimal quantity of fertilizer application, as well as the most efficient irrigation system with the least environmental impact, were suggested for further study. Besides, Napier's age may affect the crop yield and continue to the amount of carbon footprint of Napier plantation, the study period might be extended for this reason.

The authors are grateful to the fund for the general scientific research of K ing M ongkut's U niversity of Technology North Bangkok (KM UTNB).

\section{References}

1. Department of A Iternative Energy Development and Efficiency, Ministry of Energy, Thailand (2018). Energy Situation in 2018, URL: https://www.dede.go.th/download/stat62/sit_2_61_dec.pdf 
2. National News Bureau of Thailand (2019). Energy Ministry Increase Renewable Energy Ratio, URL: https://thainews.prd.go.th/en/news/detail/TCATG 1 90704144632219

3. V. Strezov, T.J. Evans, C. Hayman, Bioresour Technol. 99, 8394-8399 (2008)

4. S.Wijitphan, P. Lowilai, Effects of cutting interval on yields and nutritive values of King Napier Grass (Pennisetum purpureum cv. King grass), URL: http: / / www. resjournal. kku. ac. th/ - abstract/ 16- 3215.pdf

5. Thai Civil Rights and Investigative Journalism (2019). PDP 2018 Adaptation, URL: https://www.tcijthai.com/news/2019/8/scoop/9323

6. Energy Policy and Planning Office, Ministry of Energy (2018). The Study of Energy Conservation and Renewable Energy Potentials, URL: http://www.energyplatform.in.th/sys2/data/file_dl/08 /Public\%20Report.pdf

7. P. Bangprasit, O. Chavalpari, P. Usapein, International Conference on Green Energy and Applications (IEEE 2017) (2017)

8. P. Thanarak, B. Thanomnim, P. Maneechot, B urapha Science J ournal. 20, 1 (2015)

9. S. Udomsin, W. Rean-aree (2016). Research and Design Biogas of the $2.5 \mathrm{~kW}$ Elecric Power from Napier Grass for Household, URL: http://ir.swu.ac.th/xmlui/bitstream/handle/123456789 /5087/PR 02397.pdf?sequence $=1$

10. D. M ongar, C. Dendup, Thukten, H. Nirola, K. Rai, K. W angchuk, Trop. Grassl. - Forrajes Tropicales. 3 (2015)
11. B.T. Nijaguna. Biogas Technology, JSS Academy of Technical Education Bangalore, (2006)

12. Energy Research Center, M aejo University (2012). The potential of biogas production from energy crops by using Dry Anaerobic Digestion Technology with Circulating Leachate, Energy of Policy and Planning O ffice, M inistry of Energy

13. Prachinburi Meteorological Station, Prachinburi Climate Infromation, URL: http://www. prachin.tmd. go.th

14. Faculty of Agriculture, Ubon Ratchathani University, Napier Pakchong 1 grass plantation guidelines, URL: http://www.agri.ubu.ac.th

15. ISO 14044, Environmental management-Life Cycle Assessment - Principles and Framework (2006)

16. C. Suwan, S.H. Gheewala, International J ournal of Environment and Waste $M$ anagement 10, 2/3 (2012)

17. Thai Greenhouse Gas Management Organization. The Guidelines for Product Carbon Footprint Assessment (2019)

18. Thailand greenhouse gas management organization, Greenhouse gas Emission Factors, URL: http:/thaicarbonlabel.tgo.or.th/admin/uploadfiles/e mission/ts_f2e7bb377d.pdf

19. Thailand greenhouse gas management organization, Greenhouse gas Emission factors for organization carbon footprint, URL: http://cfologov.com/search/searchData.

20. W. Kamutavanich. A Comparative Study of Power Generation Technology Suitable for Napier Grass. Thammasat University (2013). 